\title{
PENYELENGGARAAN PEMILIHAN KEPALA DAERAH SECARA LANGSUNG DAN DEMOKRATIS SEBAGAI BENTUK PERWUJUDAN HAK ASASI POLITIK MASYARAKAT DI INDONESIA
}

\begin{abstract}
Oleh:
Sarbaini *

ABSTRAK

Pasal 1 ayat (2) UUD Tahun 1945 secara tegas menyatakan bahwa kedaulatan ada ditangan rakyat dan dilaksanakan menurut UUD. Menurut UUD secara tersurat dan tersirat, warga negara berhak memilih diantaranya Kepala Daerah. Penyelenggaraan pemilihan kepala daerah (Pilkada) adalah pemilihan kepala daerah yang dilakukan secara langung, umum, bebas dan rahasia oleh mayarakat setempat maka pemilukada secara langsung sangat erat kaitannya dengan demokrasi di mana kedaulatan terletak ditangan rakyat. Seharusnya rakyat adalah subyek yang menentukan, bukan obyek yang ditentukan, baik dalarn lingkup perpolitikan nasional maupun lokal (daerah). Masyarakatpun telah sangat paham banhwa Indonesia bukan Negara kerajaan (monarki), tetapi Negara modern yang mendasarkan politiknya adalah sistern demokrasi. Dalam penyelenggaraan pemerintahan daerah di Indonesia upaya pemilihan kepala daerah secara langsung ini telah berlangsung atau telah dilakukan sejak tahun 2005, yang didasarkan pada ketentuan UU No. 32 Tahun 2004 tentang Pemerintahan Daerah. Dalam pelaksanaan pemilihan kepala daerah secara langsung selama ini, nuansa yang paling menonjol adalah maraknya sengketa pemilihan kepala daerah yang diajukan ke Mahkamah Konstitusi. Selain itu juga maraknya kepala daerah yang terpilih dalam pemilihan kepala daerah secara langsung yang terjerat kasus korupsi. Kabar tentang kepala daerah yang tersandung kasus korupsi tak pernah berhenti mengalir. Ironisnya, setiap minggu selalu ada kepala daerah yang ditetapkan sebagai tersangka dalam kasus korupsi. Umumnya, terjeratnya para kepala daerah itu terkait erat dengan proses pemilihan kepala daerah yang sudah menelan biaya cukup banyak. Pemilihan kepala daerah secara langsung memiliki korelasi yang sangat erat dengan pelaksanaan kedaulatan rakyat. Dengan pemilihan kepala daerah secara langsung, rakyat dapat menentukan sendiri pemimpin di daerahnya, sehingga terjalin hubungan yang erat antara kepala daerah dengan rakyat yang dapat mendorong terwujudnya penyelenggaraan pemerintahan daerah yang demokratis dan partisipatif.
\end{abstract}

Kata Kunci : PILKADA langsung, Hak Asasi Politik, Masyarakat Indonesia

\section{A. Penyelenggaraan Pemilihan Kepala Daerah Sebagai Bagian Dari Perwujudan Hak}

\section{Asasi Politik Dalam Berdemokrasi Dan Melaksanakan Kedaulatan}

Secara konstitusional Undang-Undang Dasar Tahun 1945 sebagai constitusional right menyatakan bahwa Indonesia adalah negara hukum, sebagai negara hukum salah satu elemen dasarnya adalah menyangkut tentang hak asasi manusia mulai dari perlindungan, penegakan, pemenuhan, pengakuan dan penjaminan akan hak-hak dasar warga negara. Dari

\footnotetext{
${ }^{*}$ Pengajar Program Magister Ilmu Hukum UNBARI
} 
Sarbaini, Penyelenggaraan Pemilihan Kepala Daerah Secara Langsung dan Demokratis Sebagai Bentuk Perwujudan Hak Asasi Politik Masyarakat di Indonesia

berbagai literatur hukum tata negara maupun ilmu politik kajian tentang ruang lingkup paham konstitusi (konstitusionalisme) terdiri dari:

(a) anatomi kekuasaan (kekuasaan politik) tunduk pada hukum;

(b) jaminan dan perlindungan hak-hak asasi manusia;

(c) peradilan yang bebas dan mandiri; dan

(d) pertanggungjawaban kepada rakyat (akuntabilitas publik) sebagai sendi utama dari asas kedaulatan rakyat. ${ }^{1}$

Sri Soemantri menyatakan bahwa Undang-Undang Dasar Negara Republik Indonesia Tahun 1945 sebagai konstitusi tertulis merupakan sebuah dokumen formal yang berisi:

(1) Hasil perjuangan politik bangsa di waktu yang lampau;

(2) Tingkat-tingkat tertinggi perkembangan ketatanegaraan bangsa;

(3) Pandangan tokoh-tokoh bangsa yang hendak mewujudkan, baik untuk waktu sekarang maupun untuk masa yang akan dating; dan

(4) Suatu keinginan, dengan nama perkembangan kehidupan ketatanegaraan bangsa hendak dipimpin. ${ }^{2}$

Fenomena tersebut menjadikan konstitusi sebagai hukum yang tertinggi (supremacy of law) yang harus ditaati oleh rakyat maupun oleh alat-alat kelengkapan negara, siapakah yang akan menjamin bahwa ketentuan konstitusi atau Undang-Undang Dasar benar-benar diselenggarakan menurut jiwa dan kata-kata dari naskah, baik oleh badan eksekutif maupun badan pemerintah lainnya. ${ }^{3}$ TAP MPR-RI No.XVII/MPR/1998 tentang HAM, menyatakan Pembukaan UUD Tahun 1945 telah mengamanatkan pengakuan, penghormatan, dan kehendak bagi pelaksanaan HAM dalam menyelenggarakan kehidupan bermasyarakat, berbangsa dan bernegara.

Bangsa Indonesia sebagai bagian masyarakat internasional patut menghormati hak asasi manusia yang termaktub dalam Universal Declaration of Human Rights serta instrumen internasional lainnya mengenai hak asasi manusia. HAM dan demokrasi memiliki kaitan yang sangat erat, demokrasi memberikan pengakuan lahirnya keikutsertaan publik secara luas dalam pemerintahan, peran serta publik mencerminkan adanya pengakuan kedaulatan. Aktualisasi peran publik dalam ranah pemerintahan memungkinkan untuk terciptanya keberdayaan publik. Perlindungan dan pemenuhan HAM melalui rezim yang demokratik

\footnotetext{
${ }^{1}$ Dahlan Thaib, Teori dan Hukum Konstitusi,Liberty, Yogyakarta, 2006, hal. 73

${ }^{2}$ Ibid, hal. 57

${ }^{3}$ Ibid, hal. 62
} 
Sarbaini, Penyelenggaraan Pemilihan Kepala Daerah Secara Langsung dan Demokratis Sebagai Bentuk Perwujudan Hak Asasi Politik Masyarakat di Indonesia

berpotensi besar mewujudkan kesejahteraan rakyat. $^{4}$ Sejak lahirnya Negara Kesatuan Republik Indonesia Tahun 1945 bangsa ini telah menjunjung tinggi HAM. Sikap tersebut tampak dari Pancasila dan UUD Tahun 1945, yang memuat beberapa ketentuan-ketentuan tentang penghormatan HAM warga negara. Sehingga pada praktek penyelenggaraan negara, perlindungan atau penjaminan terhadap HAM dan hak-hak warga negara (citizen's rights) atau hak-hak konstitusional warga negara (the citizen's constitusional rights) dapat terlaksana. Hak memberikan suara atau memilih (right to vote) merupakan hak dasar (basic right) setiap individu atau warga negara yang harus dijamin pemenuhannya oleh negara. Hak politik warga negara mencakup hak untuk memilih dan dipilih, penjaminan hak dipilih secara tersurat dalam UUD 1945 mulai Pasal 27 ayat (1) dan (2); Pasal 28, Pasal 28D ayat (3); Pasal 28E ayat (3).56 Sementara hak memilih juga diatur dalam Pasal 1 ayat (2); Pasal 2 ayat (1); Pasal 6A ayat (1); Pasal 19 ayat (1) dan Pasal 22C ayat (1) UUD 1945. Perumusan pada pasal-pasal tersebut sangat jelas bahwa tidak dibenarkan adanya diskriminasi mengenai ras, kekayaan, agama dan keturunan.

Setiap warga negara mempunyai hak-hak yang sama dan implementasinya hak dan kewajiban pun harus bersama-sama. ${ }^{5}$ Konkritisasi dari ketentuan-ketentuan tersebut diatur lebih lanjut dalam peraturan perundang-undangan dibawahnya, sesuai ketentuan yang ada dalam Undang-Undang tentang peraturan perundang-undangan di Indonesia. Undang-Undang tentang HAM yang secara nyata memberikan pengakuan terhadap hak-hak warga negara yaitu:

(1) Hak untuk hidup;

(2) Hak berkeluarga dan melanjutkan keturunan;

(3) Hak mengembangkan diri;

(4) Hak memperoleh keadilan;

(5) Hak atas kebebasan pribadi;

(6) Hak atas rasa aman;

(7) Hak atas kesejahteraan;

(8) Hak turut serta dalam pemerintahan;

(9) Hak wanita; dan

(10) Hak anak.

${ }^{4}$ Majda El Muhtaj, Dimensi-Dimensi HAM Mengurai Hak Ekonomi, Sosial, dan Budaya, Jakarta, PT. Rajawali Pers, 2008, hal. 45.

${ }^{5}$ A.Gunawan Setiardja, Hak-Hak Asasi Manusia Berdasarkan Ideologi Pancasila, Kanisius, Yogyakarta, 1993, hal. 117. 
Sarbaini, Penyelenggaraan Pemilihan Kepala Daerah Secara Langsung dan Demokratis Sebagai Bentuk Perwujudan Hak Asasi Politik Masyarakat di Indonesia

Pada point (8) secara nyata negara memberikan pengakuan kepada setiap warga negara untuk ikut serta dalam pemerintahan baik dalam hal hak memilih dan dipilih. UU No. 39 Tahun 1999 tentang HAM khususnya Pasal 43:

(1) Setiap warga negara berhak untuk dipilih dan memilih dalam pemilihan umum berdasarkan persamaan hak melalui pemungutan suara yang langsung, umum, bebas, rahasia, jujur, dan adil sesuai dengan ketentuan peraturan perundang-undangan;

(2) Setiap warga negara berhak turut serta dalam pemerintahan dengan langsung atau dengan perantaraan wakil yang dipilihnya dengan bebas, menurut cara yang ditentukan dalam peraturan perundang-undangan.

(3) Setiap warga negara dapat diangkat dalam setiap jabatan pemerintahan.

Menurut Ramdlon Naning, HAM dapat dibedakan dalam:

(1) Hak-hak asasi pribadi (personal right);

(2) Hak-hak asasi ekonomi (property rights);

(3) Hak-hak asasi politik (political rights);

(4) Hak-hak asasi untuk mendapatkan perlakuan yang sama dalam hukum dan pemerintahan (right of legal equality);

(5) Hak-hak asasi sosial dan kebudayaan (social and culture rights); dan

(6) Hak asasi untuk mendapatkan perlakuan yang sama di muka hukum dalam tata cara peradilan dan perlindungan (procedural rights). ${ }^{6}$

Pasal 25 Undang-Undang Nomor 12 Tahun 2005 tentang Pengesahan International Covenant On Civil And Political Rights (Kovenan Internasional tentang Hak-Hak Sipil dan Politik) menyebutkan bahwa negara Indonesia mengakui dan melindungi hak setiap warga negara untuk mengambil bagian dalam pelaksanaan urusan-urusan publik, hak memilih dan dipilih, serta hak atas akses terhadap pelayanan publik. Pada tanggal 28 Oktober 2005, Indonesia meratifikasi International Covenant on Civil and Political Right (ICCPR) atau Kovenan Internasional tentang Hak-Hak Sipil dan Politik dengan disahkannya UndangUndang tentang Ratifikasi Kovenan Internasional tentang Hak-Hak Sipil dan Politik. Kovenan ini mengukuhkan pokok- pokok hak asasi manusia di bidang sipil dan politik yang tercantum dalam Universal Declaration of Human Rights (Deklarasi Universal Hak Asasi Manusia) sehingga menjadi ketentuan-ketentuan yang mengikat secara hukum dan penjabarannya mencakup pokok-pokok lain yang terkait, Kovenan tersebut terdiri dari

${ }^{6}$ H.Rosjidi Ranggawidjaja, Pembatasan Konstitusional Hak Warga Negara untuk Memilih dan Dipilih dalam Jabatan Publik, Jurnal Konstitusi PSKN-FH Universitas Padjajaran, Volume II Nomor2, November 2010, Jakarta, FH Unpad dengan Mahkamah Konstitusi hal. 38. 
Sarbaini, Penyelenggaraan Pemilihan Kepala Daerah Secara Langsung dan Demokratis Sebagai Bentuk Perwujudan Hak Asasi Politik Masyarakat di Indonesia

pembukaan dan Pasal-Pasal yang mencakup 6 bab dan 53 Pasal. ICCPR pada dasarnya memuat ketentuan mengenai pembatasan penggunaan kewenangan oleh aparat represif negara, khususnya aparatur represif negara yang menjadi Negara-Negara Pihak dalam ICCPR, Makanya hak-hak yang terhimpun didalamnya juga sering disebut sebagai hak-hak negatif (negative rights).

Artinya, hak-hak dan kebebasan yang dijamin didalamnya akan dapat terpenuhi apabila peran negara terbatasi atau terlihat minus. Tetapi apabila negara berperan intervensionis, tak bisa dielakkan hak-hak dan kebebasan yang diatur di dalamnya akan dilanggar oleh negara. Inilah yang membedakan dengan model legislasi Kovenan Internasional Hak-Hak Ekonomi, Sosial dan Budaya (KIHESB) yang justru menuntut peran maksimal negara. Negara justru melanggar hak-hak yang dijamin didalamnya apabila negara tidak berperan secara aktif atau menunjukkan peran yang minus. KIHESB karena itu sering disebut hak-hak positif (positive rights). ${ }^{7}$

Pada sisi lain Ifdhal Kasim dalam kata pengantar buku Hak Sipil dan Politik EsaiEsai Pilihan, membuat dua klasifikasi terhadap hak-hak dan kebebasan dasar yang tercantum dalam ICCPR. Klasifikasi yang pertama, adalah hak-hak dalam jenis non-derogable rights, yaitu hak-hak yang bersifat absolut dan tidak boleh dikurangi pemenuhannya oleh NegaraNegara Pihak, walaupun dalam keadaan darurat sekalipun. Hak-hak yang termasuk dalam jenis ini adalah:

(1) Hak atas hidup (rights to life);

(2) Hak bebas dari penyiksaan (rights to be free from torture);

(3) Hak bebas dari perbudakan (rights to be free from slavery);

(4) Hak bebas dari penahanan karena gagal memenuhi perjanjian (hutang);

(5) Hak bebas dari pemidanaan yang berlaku surut;

(6) Hak sebagai subyek hukum dan

(7) Hak atas kebebasan berpikir, keyakinan dan agama. ${ }^{8}$

Negara-negara pihak yang melakukan pelanggaran terhadap hak-hak dalam jenis ini seringkali akan mendapat kecaman sebagai negara, yang telah melakukan pelanggaran serius hak asasi manusia (gross violation of human rights).

${ }^{7}$ Ifdhal Kasim (Editor), Hak Sipil dan Politik Esai-Esai Pilihan. Cetakan Pertama. Jakarta. Lembaga Studi dan Advokasi Masyarakat (ELSAM), 2001, hal. 49

${ }^{8}$ Ibid, hal. 51 
Sarbaini, Penyelenggaraan Pemilihan Kepala Daerah Secara Langsung dan Demokratis Sebagai Bentuk Perwujudan Hak Asasi Politik Masyarakat di Indonesia

Kelompok kedua adalah hak-hak dalam jenis derogable, yakni hak-hak yang boleh dikurangi atau dibatasi dalam pemenuhannya oleh Negara-Negara Pihak. Hak dan kebebasan yang tergantung dalam jenis ini adalah:

(a) hak atas kebebasan berkumpul secara damai;

(b) hak atas kebebasan berserikat, termasuk membentuk dan menjadi anggota serikat buruh;

(c) hak atas kebebasan menyatakan pendapat atau berekspresi, termasuk kebebasan mencari, menerima dan memberikan informasi dari segala gagasan tanpa memperhatikan batas (baik melalui lisan maupun tulisan).

Negara-negara pihak dalam ICCPR diperbolehkan mengurangi atau mengadakan penyimpangan atas kewajiban dalam memenuhi hak-hak tersebut. Tetapi penyimpangan itu hanya dapat dilakukan apabila sebanding dengan ancaman yang dihadapi dan tidak bersifat diskriminatif, yaitu demi menjaga keamanan nasional atau ketertiban umum atau kesehatan atau moralitas umum; dan menghormati hak atau kebebasan orang lain. Rosalyn Higgins menyebut ketentuan ini sebagai ketentuan "clawback", yang memberikan suatu keleluasaan kepada negara yang dapat disalahgunakan oleh negara. Untuk menghindari hal ini ICCPR menggariskan bahwa hak-hak tersebut tidak boleh dibatasi melebihi dari yang ditetapkan oleh kovenan ini. Selain diharuskan menyampaikan alasan-alasan mengapa pembatasan tersebut dilakukan kepada semua Negara-Negara Pihak ICCPR.

Dahulunya pada masa berlakunya Undang-Undang Nomor 32 Tahun 2004 juncto Undang-Undang Nomor 10 Tahun 2008 tentang pemerintahan daerah, Peraturan Pemerintah Nomor 6 Tahun 2005 tentang pemilihan, pengesahan, pengangkatan dan pemberhentian kepala daerah dan wakil kepala daerah dan Peraturan Komisi Pemilihan Umum Nomor 10 Tahun 2008 tentang tata cara penyusunan daftar pemilih untuk pemilihan umum anggota dewan perwakilan rakyat, dewan perwakilan daerah dan dewan perwakilan rakyat daerah menyebutkan bahwa seorang warga negara memiliki hak memilih apabila warga negara Indonesia yang telah genap berumur 17 (tujuh belas) tahun atau lebih atau sudah pernah kawin. Selanjutnya diatur bahwa daftar pemilih sebagaimana dimaksud sekurang-kurangnya memuat nomor induk kependudukan, nama, tanggal lahir, jenis kelamin, dan alamat warga negara Indonesia yang mempunyai hak memilih. Menurut Rosjidi Ranggawidjaja, pembatasan tersebut dapat dikategorikan sebagai persyaratan prosedural. Apapun persyaratan 
yang ditetapkan akan merupakan suatu pembatasan terhadap hak memilih warga negara. ${ }^{9}$ Dan pada akhirnya ini akan dijadikan alasan untuk melakukan constitusional review terhadap undang-undang, karena sudah sangat jelas bahwa hak memilih dan dipilih seorang warga negara yang dijamin dalam UUD dan harus dilindungi dan diberikan oleh negara. Namun dalam Undang-Undang Pemilu dan peraturan pelaksana dibawahnya memberikan batasan umur, prosedural sampai administrasi.

Ketentuan UUD 1945 Pasal 28 ayat (1) dan ayat (2), negara dapat pembatasan atas dasar pertimbangan moral, nilai agama, keamanan, ketertiban umum dalam suatu masyarakat demokratis. ${ }^{10}$ Selanjutnya Undang-Undang tentang administrasi kependudukan mengatakan KTP, adalah identitas resmi penduduk sebagai bukti diri yang diterbitkan oleh instansi pelaksana yang berlaku di seluruh wilayah NKRI. Penduduk adalah warga negara Indonesia dan orang asing yang bertempat tinggal di Indonesia. Pendefenisian ini memberikan rumusan bahwa setiap orang yang bertempat tinggal di wilayah NKRI wajib diberikan identitas kependudukan oleh negara, sesuai dengan asas ius solli dan ius sanguinis. ${ }^{11}$ Hak politik pada hakekatnya mempunyai sifat melindungi individu dari penyalahgunaan kekuasaan oleh pihak penguasa. Karena itu, dalam mendukung pelaksanaannya peranan pemerintah perlu diatur melalui perundang-undangan, agar campur tangannya dalam kehidupan warga masyarakat melampaui batas-batas tertentu. Hak-hak politik biasanya ditetapkan dan diakui sepenuhnya oleh konstitusi berdasarkan keanggotaan sebagai warga negara. Artinya, hak-hak ini tidak berlaku kecuali bagi warga negara setempat, bukan warga asing. Penegasan konstitusi hak politik warga negara, tertuang dalam UUD Tahun 1945 Pasal 27 ayat (1) dinyatakan bahwa, "Segala warga negara bersamaan kedudukannya di dalam hukum dan pemerintahan dan wajib menjunjung hukum dan pemerintahan itu dengan tidak ada kecualinya". Pasal ini menjelaskan bahwa setiap warga negara, yaitu orang Indonesia asli maupun bangsa lain yang disahkan Undang-Undang sebagai warga negara, mempunyai kedudukan yang sama di mata hukum dan pemerintahan. Setiap warga negara juga berhak untuk memperoleh kesempatan yang sama dalam pemerintahan (Undang-Undang Dasar 1945 Pasal 28D ayat (3)).

Penegasan konstitusi hak politik warga negara, tertuang dalam Undang Undang tentang HAM khusus Pasal 43:

${ }^{9}$ H. Rosjidi Ranggawidjaja, Pembatasan Hak Asasi Manusia Menurut Hukum dan Konvensi Internasional,Djambatan, Jakarta, 2000, hal.113.

${ }^{10} \mathrm{Ibid}$, hal. 115

${ }^{11}$ Mahmuda, Hukum Kewarganegaraan 
(1) Setiap warga negara berhak untuk dipilih dan memilih dalam pemilihan umum berdasarkan persamaan hak melalui pemungutan suara yang langsung, umum, bebas, rahasia, jujur, dan adil sesuai dengan ketentuan peraturan perundang- undangan.

(2) Setiap warga negara berhak turut serta dalam pemerintahan dengan langsung atau dengan perantaraan wakil yang dipilihnya dengan bebas, menurut cara yang ditentukan dalam peraturan perundang-undangan.

(3) Setiap warga negara dapat diangkat dalam setiap jabatan pemerintahan.

Penegasan konstitusi hak politik warga negara, tertuang dalam kovenan hak sipil dan politik ditegaskan Pasal 25 "Setiap warga negara harus mempunyai hak dan kesempatan, tanpa pembedaan apapun" sebagaimana yang dimaksud dalam Pasal 2 dan tanpa pembatasan yang tidak layak, untuk:

(a) Ikut serta dalam pelaksanaan urusan pemerintahan, baik secara langsung ataupun melalui wakil-wakil yang dipilih secara bebas;

(b) Memilih dan dipilih pada pemilihan umum berkala yang murni, dan dengan hak pilih yang universal dan sama, serta dilakukan melalui pemungutan suara secara rahasia untuk menjamin kebebasan menyatakan keinginan dari para pemilih;

(c) Memperoleh akses pada pelayanan umum di negaranya atas dasar persamaan dalam arti umum.

Hak-hak asasi manusia, oleh PBB dalam sidang umumnya pada tanggal 10 Desember 1984 dalam Piagam HAM tersebut telah berhasil ditetapkan secara rinci beberapa hak politik sebagai berikut: hak untuk mempunyai dan menyatakan pendapat tanpa mengalami gangguan (Pasal 19), hak atas kebebasan berkumpul dan berserikat secara tenang (Pasal 20 ayat 1), hak untuk ikut serta dalam pemerintahan negara (Pasal 21 ayat 1), hak untuk ikut serta dalam pemilu yang dilakukan secara periode, serentak, wajar, bebas, dan rahasia (Pasal 21 ayat 3) dan lain-lain. Menurut piagam PBB dan perjanjian hak-hak sipil dan politik serta defenisi hak politik dapat di klasifikasikan menjadi tujuh macam hak politik, yaitu:

a. hak untuk memiliki dan menyatakan pendapat dengan tenang

b. hak untuk berserikat dan berkumpul

c. hak untuk berpartisipasi dalam pemerintahan negara

d. hak untuk ikut serta dalam pemilu

e. hak kebebasan menentukan status politik

f. hak untuk memilih dan dipilih 
Sarbaini, Penyelenggaraan Pemilihan Kepala Daerah Secara Langsung dan Demokratis Sebagai Bentuk Perwujudan Hak Asasi Politik Masyarakat di Indonesia

g. hak untuk mencalonkan diri dan memegang jabatan umum dalam negara.

Soepomo menyatakan bahwa negara harus menjaga supaya tidak ada warga negara yang memiliki kewarganegaraan ganda (dwikewarganegaraan atau dubbele onderdaanschap) dan juga yang tidak mempunyai kewarganegaraan (staatloosheid). Hal ini harus diatur dengan sistem dan peraturan perundang-undangan di Indonesia. Untuk itu, Soepomo mengajukan dasar kewarganegaraan Indonesia, yaitu: (1) Ius Sanguinis (prinsip keturunan) dan (2) Ius Soli (prinsip teritiorial). ${ }^{12}$

Isi kedudukan yang disimbolkan dengan Kartu Tanda Penduduk (KTP) sebagai warga negara adalah; hanya warga negara mempunyai hak-hak politik, misalnya hak memilih dan dipilih dan hanya warga negara mempunyai hak diangkat menjadi jabatan negara. Pada dasarnya status suatu kewarganegaraan seseorang memiliki dua aspek, yaitu: aspek hukum, dimama kewarganegaraan merupakan suatu status hukum kewarganegaraan, suatu kompleks hak dan kewajiban, khususnya dibidang hukum publik yang dimiliki oleh warga negara dan yang tidak dimiliki oleh orang asing.

UU Nomor 23 Tahun 2006 tentang Administrasi Kependudukan memuat bahwa KTP, adalah identitas resmi Penduduk sebagai bukti diri yang diterbitkan oleh Instansi Pelaksana yang berlaku di seluruh wilayah Negara Kesatuan Republik Indonesia. Penduduk adalah warga negara indonesia dan orang asing yang bertempat tinggal di Indonesia. Warga negara Indonesia adalah orang-orang bangsa Indonesia asli dan orang-orang bangsa lain yang disahkan dengan undang-undang sebagai warga negara Indonesia. Sementara Pasal 1 ayat (2) UUD 1945, secara tersurat memuat tentang kedaulatan ada ditangan rakyat dan dilaksanakan menurut UUD. Menurut UUD secara tersurat dan tersirat, warga negara berhak memilih DPR, DPD, DPRD, Presiden dan Wakil Presiden, Gubernur, Bupati dan Kepala Desa.

Konstitusi memuat bahwa Indonesia adalah negara hukum yang salah satu elemen dasarnya adalah pemenuhan akan hak-hak dasar manusia. Terdapat beberapa pertimbangan hukum dalam kasus ini yaitu:

1. Adanya pengakuan, penjaminan dan perlindungan HAM Warga Negara Indonesia oleh Negara.

2. Negara dijalankan atas nama Kedaulatan Rakyat.

3. Asas lex priori de rogat legi infriori dimana perundangan lebih tinggi diberlakukan dari pada perundangan yang lebih rendah, asas ini sesuai dengan teorinya Hans

\footnotetext{
${ }^{12}$ Naskah Komprehensif Perubahan Undang-Undang Dasar Negara Republik Indonesia Tahun 1945,Buku VIII Warga Negara dan Penduduk, Hak Asasi Manusia dan Agama, Jakarta, MahkamahKonstitusi Republik Indonesia. 2010. hal. 14
} 
Kelsen yaitu perundangan yang lebih rendah harus mengikuti perundangan yang lebih tinggi.

4. Negara oleh hukum dipandang sebagai sesuatu yang mandiri, pemikul hak dan kewajiban seperti orang pribadi (natuurijk persoon);

5. Hukum Administrasi Negara mengenal Freies Ermessen dimana Pejabat atau badan administrasi negara dilekati wewenang untuk membuat berbagai keputusan selain menurut ketentuan peraturan perundang-undangan,pelaksanaan wewenang dilakukan berdasarkan atas kebebasan bertindak (beleidsvrijheid atau beoordelingsvrijheid).

6. Semestinya Pemerintah dapat mempertimbangkan pemenuhan hak politik yang bukan berarti menyelesaikan persoalan agraria. ${ }^{13}$

Artinya persoalaan KTP dapat dikesampingkan bila pertimbangannya terhadap Penjaminan, perlindungan dan pemenuhan hak politik warganegara. Ada beberapa solusi hukum yang ditawarkan yaitu; Pertama, Pengakuan hak politik baik universalis dan nasional telah diakui oleh Negara. Persoalan KTP dapat dikesampingkan melalui keputusan administrasi negara yang dapat dilakukan oleh pemangku jabatan apabila terjadi kekosongan hukum.

Perlu diingat pemberian hak pilih merupakan pelaksanaan dari prinsip bernegara dan pengabaian hak pilih merupakan penghianatan atas kedaulatan rakyat serta mencederai konstitusional right dan apabila terjadi pengabaian pasti terjadi sengketa hukum ketatanegaraan melalui Mahkamah Konstitusi. Kedua, Negara segera menyelesaikan konflik agraria setelah hak politik mereka diberikan, sesuai fungsi negara yaitu mewujudkan keadilan, ketertiban, dan perwujudan nilai-nilai ideal seperti kemerdekaan atau kebebasan dan kesejahteraan atau kemakmuran bersama sebagaimana dirumuskan sebagai tujuan bernegara oleh para pendiri negara (the fouding fathers).

Pencabutan atau pengabaian hak politik warganegara harus melalui putusan pengadilan jadi tidak bisa secara langsung diabaikan oleh pemerintah. Prinsip HAM universal menyebutkan negara wajib menjamin hak memilih (right to vote) dan hak untuk dipilih (right to be elected). Karenanya, setiap negara diminta untuk menerbitkan peraturan perundangundangan dan upaya lain yang diperlukan untuk memastikan setiap warga negara tanpa diskriminasi berdasarkan apa pun memperoleh kesempatan yang efektif menikmati hak ini supaya tercapailah kepastian hukum, keadilan dan kemanfaatan. Mekanisme Penghilangan hak pilih hak politik yang diatur secara tegas oleh UUD Tahun 1945 diantaranya bahwa

\footnotetext{
${ }^{13}$ Ibid
} 
Sarbaini, Penyelenggaraan Pemilihan Kepala Daerah Secara Langsung dan Demokratis Sebagai Bentuk Perwujudan Hak Asasi Politik Masyarakat di Indonesia

setiap warga negara berhak untuk berserikat, berkumpul, dan menyatakan pendapatnya secara damai; berhak untuk memilih dan dipilih dalam rangka lembaga perwakilan rakyat.

Syarat-syarat untuk dapat memilih dalam pemilu yakni pemilih terdaftar sebagai pemilih; pemilih nyata-nyata tidak terganggu jiwa/ingatannya; pemilih tidak sedang menjalani hukuman pidana kurungan yang diancam hukuman 5 (lima) tahun atau lebih; serta pemilih tidak sedang dicabut hak pilihnya berdasarkan putusan pengadilan; di dalam UU Nomor 10 Tahun 2008 tentang Pemilu, PP Nomor 6 Tahun 2005 Tentang Pemilihan, Pengesahan Pengangkatan, dan Pemberhentian Kepala Daerah dan Wakil Kepala Daerah dan Peraturan KPU No. 10 Tahun 2008 tentang Tata Cara Penyusunan Daftar Pemilu menyebutkan Pemilih adalah Warga Negara Indonesia yang telah genap berumur 17 (tujuh belas) tahun atau lebih atau sudah atau pernah kawin. Berdasarkan Peraturan KPU, KPU Kabupaten/Kota menggunakan data kependudukan sebagai bahan penyusunan daftar pemilih. Pasal 5 Peraturan KPU Nomor 10 Tahun 2008 mengatakan daftar pemilih sebagai mana dimaksud sekurang-kurangnya memuat nomor induk kependudukan, nama, tanggal lahir, jenis kelamin, dan alamat Warga Negara Indonesia yang mempunyai hak memilih.

Sebagaimana diuraikan sebelumnya pemilu merupakan salah satu sarana pelaksanaan kedaulatan rakyat dan HAM dalam bidang politik. Hal tersebut diwujudkan dengan adanya hak pilih dalam pemilu yang dimiliki oleh setiap warga negara. hal ini ditegaskan dalam Undang-Undang tentang HAM Pasal 43 ayat (1) bahwa: "Setiap warga negara berhak untuk dipilih dan memilih dalam pemilihan umum berdasarkan persamaan hak melalui pemungutan suara yang langsung, umum, bebas, rahasia, jujur, dan adil sesuai dengan ketentuan perundang-undangan. Pada Pasal 1 ayat (2) UUD Tahun 1945 secara tegas menyatakan bahwa kedaulatan ada ditangan rakyat dan dilaksanakan menurut UUD. Menurut UUD secara tersurat dan tersirat, warga negara berhak memilih DPR, DPD, DPRD, Presiden dan Wakil Presiden, Gubernur, Bupati dan Kepala Desa. Konstitusi telah secara tegas menyatakan bahwa Indonesia adalah negara hukum yang salah satu elemen dasarnya adalah pemenuhan akan hak-hak dasar manusia. Undang-Undang Nomor 42 Tahun 2008 tentang Pemilihan Umum Presiden dan Wakil Presiden, yakni dengan adanya ketentuan Pasal 28 dan 111 ayat (1) yang menyebabkan seorang warga negara kehilangan hak memilih ketika tidak mendaftar sebagai pemilih atau tidak tercantum dalam Daftar Pemilih Tetap (DPT) adalah tidak adil.

Pada satu sisi, Undang-Undang ini memberikan kewajiban untuk mendaftar semua warga yang telah berusia 17 tahun dan/atau sudah pernah kawin kepada penyelenggara 
Sarbaini, Penyelenggaraan Pemilihan Kepala Daerah Secara Langsung dan Demokratis Sebagai Bentuk Perwujudan Hak Asasi Politik Masyarakat di Indonesia

pemilu. Namun, disisi lain, bila penyelenggara Pemilu lalai mendaftar seorang warga negara yang telah memiliki hak memilih, warga negara yang bersangkutan kehilangan hak memilihnya. Kesalahan atau kelalaian penyelenggara Pemilu ditimpakan akibatnya kepada warga negara. Pemilu merupakan sarana berdemokrasi bagi warga negara dan merupakan hak warga negara yang dijamin oleh konsitusi, yaitu hak atas kesempatan yang sama dalam hukum dan pemerintahan sebagaimana diatur dalam UUD 1945 yang berbunyi "Segala warga negara bersamaan kedudukannya di dalam hukum dan pemerintahan dan wajib menjunjung hukum dan pemerintahan itu dengan tidak ada kecualinya", dan "Setiap orang berhak atas pengakuan jaminan, perlindungan, dan kepastian hukum yang adil serta perlakuan yang sama dihadapan hukum" serta prinsip persamaan kesempatan (equal opportunity principle).

Todung Mulya Lubis menyatakan: Bahwa dengan hilangnya hak memilih sebagian besar warga Negara, secara tidak langsung Negara telah melanggar hak-hak asasi manusia yang pada saat ini sedang gencar-gencarnya didengungkan oleh sebagian besar Negaranegara di dunia berupa hak untuk dipilih dan hak untuk memilih...The government seemed ready to adopt some kind of human right policy, despite the fact that many suspected the government's sincerity. ${ }^{14}$ Pasal 28 dan Pasal 111 Undang-Undang tentang Pemilihan Umum Presiden dan Wakil Presiden hanya memberikan hak tersebut pada warga negara yang sudah terdaftar dalam Daftar Pemilih Tetap atau Daftar Pemilih Tambahan. Sehingga warga negara yang telah memenuhi syarat untuk memilih, akan tetapi masih belum terdaftar dalam DPT telah dirugikan atas keberlakuan pasal dalam undang-undang tersebut.

Setelah pengujian (judicial review) sebagai solusi atas Pasal 28 dan Pasal 111 Undang-Undang tentang Pemilihan Umum Presiden dan Wakil Presiden yang kemudian diputuskan berdasarkan putusan Mahkamah Konstitusi Nomor 102/PUU- VII/2009, maka hak asasi yang dijamin dalam konstitusi semakin dikuatkan sehingga warga negara yang tidak terdaftar dalam Daftar Pemilh Tetap (DPT) bisa tetap menggunakan haknya dengan kartu Tanda Penduduk (KTP) disertai Kartu Keluarga (KK) atau Paspor bagi warga negara indonesia yang berada di luar Indonesia dengan syarat-syarat tertentu. Akibat hukum yang timbulkan dari putusan ini ialah menyatakan Pasal 28 dan Pasal 111 Undang-Undang Nomor 42 Tahun 2008 tentang Pemilihan Umum Presiden dan Wakil adalah konstitusional

\footnotetext{
${ }^{14}$ Todung Mulya Lubis dalm Satya Arinanto, Politik Hukum 2, Program Pasca Sarjana Fakultas Hukum Universitas Indonesia,Jakarta, 2001, hal. 211.
} 
Sarbaini, Penyelenggaraan Pemilihan Kepala Daerah Secara Langsung dan Demokratis Sebagai Bentuk Perwujudan Hak Asasi Politik Masyarakat di Indonesia

sepanjang diartikan mencakup warga negara yang tidak terdaftar dalam Daftar Pemilih Tetap dengan syarat dan cara yang ditentukan didalam putusan tersebut. Dengan adanya judicial review ini maka hak-hak masyarakat yang hilang dapat dikembalikan melalui sebuah proses peradilan fair, sehingga benturan-benturan kepentingan bisa diselesaikan dengan seadil-adil berdasarkan amanah konstitusi, sehingga penyelesaian secara jalur hukum mendapatkan tempat dihati masyarakat. The notions of checks and balance, separation of power, independence of thejudiciary, due process of law and judicial review, wich are vital foundations of rechstaat. ${ }^{15}$

Soal penggunaan KTP ini, hakim konstitusi Arsyad Sanusi mengatakan, KPU dapat langsung melaksanakannya dengan berdasarkan pada putusan Mahkamah Konstitusi. Penggunaan KTP tidak memerlukan peraturan pemerintah pengganti undang-undang (Perpu) untuk melaksanakannya karena putusan MK bersifat langsung dapat dilaksanakan. Hal ini sesuai dengan pandangan Satjipto Rahardjo dengan aliran progresifnya. Kebenaran hukum tidak dapat ditafsirkan semata-mata sebagai kebenaran undang-undang, tetapi harus dipahami sebagai kebenaran prinsip keadilan yang mendasari undang-undang. ${ }^{16}$ Menurut Satjipto Rahardjo rangkaian permasalahan dalam dunia pengembanan hukum di Indonesia sudah luar biasa dan sudah sedemikian gawatnya. Penyelesaiannya tidak dapat dilakukan dengan caracara berhukum yang biasa dan konvensional. Oleh karena itu diperlukan cara hukum yang luar biasa pula. Salah satu cara berhukum luar biasa yang ditawarkan oleh Satjipto Rahardjo untuk menghadapi kemelut dalam dunia penegakan hukum adalah suatu tipe penegakan hukum progresif. ${ }^{17}$

\section{B. Sistem Pemilihan Umum dan Pemilihan Kepala Daerah Menurut Sistem Ketatanegaraan Indonesia}

Penyelenggaraan pemilihan kepala daerah (Pilkada) adalah pemilihan kepala daerah yang dilakukan secara langung, umum, bebas dan rahasia oleh mayarakat setempat maka pemilukada secara langsung sangat erat kaitannya dengan demokrasi di mana kedaulatan terletak ditangan rakyat. Seharusnya rakyat adalah subyek yang menentukan, bukan obyek yang ditentukan, baik dalarn lingkup perpolitikan nasional maupun lokal (daerah). Masyarakatpun telah sangat paham banhwa Indonesia bukan Negara kerajaan (monarki),

\footnotetext{
${ }^{15} \mathrm{Ibid}$

${ }^{16}$ Satya Arinanto, Politik Hukum 3, Program Pasca Sarjana Fakultas Hukum Universitas Indonesia,Jakarta, 2001, hal. 276

${ }^{17}$ Satjipto Rahardjo, Penegakan Hukum Sosiologis Suatu Tinjauan Sosiologis, Genta Publishing,Semarang, 2009, hal 11 .
} 
Sarbaini, Penyelenggaraan Pemilihan Kepala Daerah Secara Langsung dan Demokratis Sebagai Bentuk Perwujudan Hak Asasi Politik Masyarakat di Indonesia

tetapi Negara modern yang mendasarkan politiknya adalah sistern demokrasi. Dalam konstitusi dasar negara (Undang Undang Dasar 1945) ditegaskan bahwa kedaulatan terletak ditangan rakyat. Karenanya rakyat sumber utama legitimasi politik. Konsep kedaulatan rakyat memang sudah sangat klasik. Namun demikian. konsep tersebut masih terus rnenghiasi spektrurn peradaban manusia dibelahan dunia. Secara harfiah, kedaulatan rakyat berarti kekuasaan tertinggi ada ditangan rakyat. Negara yang menempatkan "kekuasaan tertinggi" pada rakyat disebut Negara demokrasi (pemerintahan dari rakyat, oleh rakyat dan untuk rakyat).

Sebagaimana diungkapkan Nick Hungtingtong ${ }^{18}$, bahwa: Demokrasi merupakan satu-satunya bentuk pemerintahan yang paling baik, walaupun ia sebagai pilihan yang buruk dan sistem pemerintahan yang paling balk, walau Ia sebagai pilihan buruk dan sistem pemerintahan yang terburuk yang pernah ada dibelahan dunia". Dari rakyat, rnaksudnya bahwa mereka yang duduk sebagai penyelenggara Negara harus terdiri dari seluruh rakyat atau dukungan oleh rakyat. Oleh rakyat, berarti penyelenggaraan Negara atau pemerintah dilakukan sendiri oleh rakyat atau yang mewakili rakyat. Sedangkan untuk rakyat maksudnya pemerintah dijalankan atau berjalan sesuai kehendak rakyat. Artinya memposisikan publik secara aktif publik menjadi kekuatan yang kritis dan responsive.” Bagaimanapun, publik yang sejati bukanlah kategori pasif melainkan aktif. Publik bukan kerumanan massa yang diam atau sekedar menjadi supporter (penggembira) publik adalah warga negara yang memiliki kesadaran dirinya, hak-haknya kewajibannya dan tanggung jawabnya serta kepentingannya.

Mereka memiliki keberanian menegaskan eksistensi diri, rnemperjuangkan pemenuhan hak-haknya, dan mendesak agar kepentingan-kepentingannya terakomodasi, melalui prosedur yang demokratis. Dalam negara demokrasi dipersyaratkan deselenggarakannya pemilihan guna mernilih para penyelengara Negara (legislatif' dan ekesekutif). Secara filosofis. Hal tersebut mengisyaratkan hubungan fundamental bahwa yang dipilih bertanggung jawab penuh kepada pemilih, publik, tidak ada pemerintahan demokratis yang tidak bertanggung jawab kepada rakyat. Ciri demokrasi terdiri atas akuntabilitas, rotasi kekuasaan, rekrutmen politik yang terbuka pemilihan umum, dan menikmati hak-hak dasar" Keterkaitan antara pemahaman kedaulatan rakyat dengan pemilu sangat jelas. Pemilu merupakan medium untuk mewujudkan kedaulatan rakyat. Paham kedaulatan rakyat secara

\footnotetext{
${ }^{18}$ Nick Hungtingtong, Paradoks Demokrasi, Yayasan Obor, Jakarta, 2005, hal.61
} 
asasi mengakui persamaan hak politik, tanpa membeda-bedakan agama, suku, ras atau kelas sosial ekonomi. Demikian juga rakyat berdiri sama di depan hukum.

Dalam demokrasi tiap individu punya otonomi. Individu merupakan satuan-satuan terkecil dalam masyarakat, yang dalam demokrasielektoral adalah voter (pemilih). Setiap individu memiliki kebebasan seluasluasnya menentukan pilihan politiknya (termasuk, bahkan memilih untuk “tidak memilih'). Otonomi dan kebebasan individu merupakan modal bagi demokrasi. Namun demikian kebebasan memilih dan tidak memilih, pada opsi 'tidak memilih" secara etika demokrasi bukan justru tidak memilih aktif dalam mempengaruhi masyarakat lain untuk melakukan tindakan yang sama dengan apa yang dilakukan yaitu tidak memilih. demokrasi dapat dipandang secara subtansial dan prosedural aturan normatif pemilu kepala daerah secara langsung.

Perkembangan demokratisasi Indonesia berjalan beriringan dengan kemerdekaan Indonesia pada tahun 1945. Demokrasi sebagai salah satu hal yang urgen dalarn rangka proses perjuangan menciptakan cita-cita kemerdekaan Indonesia, yaitu demokrasi yang berinti pada kedaulatan ada ditangan rakyat dan dilaksanakan menurut Undang-Undang Dasar (Amandemen ke 3 UUD 1945, Pasal 1 ayat (2)). Kehendak untuk menjadi Negara yang demokratis dan menata pernerintahan kita secara demokratis. merupakan kehendak yang selaras dengan suasana dasar Negara Republik Indonesia dalarn rangka perjuangan kernerdekaan itu sendiri. Sejak kemerdekaan bangsa Indonesia tahun 1945, proses demokratisasi rakyat dengan mernakai sistern perwakilan dengan melalui sarana Pemilihan Umum. Pemilihan umum dalam sejarahnya dan fungsinya banyak mengalami perubahan, Perubahan akan Pemilihan Umum ini didasari oleh Undang Undang Dasar 1945 yang kemudian di tindaklanjuti dengan Undang-Undang di bawahnya sampai pada teknis yaitu produk hukum yang di hasilkan oleh Komisi Pemilihan Umum.

Hal ini dilakukan dalam rangka untuk memberikan peluang demi terciptanya suatu hasil pemilu yang demokratis. Dalam kaitannya dengan kedaulatan rakyat maka pemilu merupakan suatu sarana untuk menciptakan kedaulatan itu sendiri dengan cara memilih wakil yang di dudukan sebagai wakil rakyat di DPR, DPRD Provinsi dan DPRD Kab/Kota. Selain itu sebagai implementasi dari pelaksanaan Undang-Undang Dasar 1945 Pasal 18 ayat (4) amandemen ke 2, yang berbunyi “ Gubernur Bupati dan Walikota masing-masing sebagai kepala pemerintah daerah Provinsi, Kabupaten dan kota dipilih secara demokratis. Maka hubungannya dengan pasal tersebut di atas maka sebagaimana kita saksikan pada bulan Juni 2005 yang merupakan musim semi demokrasi lokal, ditandai dengan dimulainya pilkada 
langsung ditanah air. Hal ini akan terulang lagi pada tahun 2010, diberbagai kabupaten Kota yang berada di wilayah administrasi Jawa Tengah akan menggelar Pemilihan Umum Kepala Daerah secara langsung. Walaupun pada realitasnya Pemilu Kepala Daerah secara langsung merniliki kelebihan dan kekurangan, narnun paling tidak dalarn konteks Indonesia sebagai Negara Demokrasi maka Pemilihan Kepala Daerah seeara langsung itu penting dan tepat untuk diterapkan. Sebagaimana kita secara seksama merenungkan pandangan Winston Churcill ${ }^{19}$ bahwa "demokrasi bukan sesuatu sistem yang sempurna. tetapi belum ada sistem polilik lain yang lebih baik darinya". Politik lokal mewarnai dinamika politik nasional sepanjang politik Indonesia, telah terjadi beberapa kali gejolak politik lokal yang mengguncang konstelasi politik Nasional. Misalnya pada fase-fase awal kemerdekaan, khususnya tahun 1950-an telah terjadi pemberontakan dibeberapa daerah, beberapa penyebab terjadinya goncangan tersebut adalah adanya ketidakpuasan antara keputusan politik pemerintah pusat yang intinya daerah mermutut adanya keadilan dalam proses pembangunan, karena mengalami berbagai kesenjangan.

Ekspresi ketidak puasan daerah tersebut, merentang dan "lunak" hingga "radikal" (bahkan wacana sampai aksi pemisahan diri dari negara kesatuan republik Indonesia (NKRI). Atas fenomena tersebut, pada awal reformasi dua wacana mengubah hentuk NKRI menjadi Negara Federal, atau membuka otonomi daerah seluas-luasnya. Dan hal tersebut maka ditetapkan otonomi, sebagai konsekuensinya lebih rinci pada Pemilu Kepala Daerah secara langsung sebagai konsekuensi otonomi (desentralisasi) pada ungkapan M.Rias Rasyid ${ }^{20}$ bahwa tujuan desentralisasi adalah: "pertama, membebaskan pemerintah pusat dan bebanbeban yang tidak perlu mengurusi urusan domestik sehingga ia berkesempatan mempelajari, memahami merespon berbagai kecenderungan global dan mengambil manfaat daripadanya. Kedua, pada saat yang sama pemerintah pusat diharapkan mampu berkonsentrasi pada rumusan kebijakan makro Nasional yang bersifat strategis. Ketiga, dengan desentralisasi, kewenangan pemerintah kedaerah, maka daerah akan mengalarni pemberdayaan yang signifikan. Dan pandangan tersebut lebih rinci dirumuskan dalam dalam UUD dan perundang undangan Indonesia.

Dalam penyelenggaraan pemerintahan daerah di Indonesia upaya pemilihan kepala daerah secara langsung ini telah berlangsung atau telah dilakukan sejak tahun 2005, yang

\footnotetext{
${ }^{19}$ Winston Churcill dalam Alafan Allian, Demokrasi dan Hak Asasi Manusia Dalam Perang (terjemahan Gramedia), Penerbit Gramedia, Jakarta, 2005, hal. 93

${ }^{20}$ M.Rias Rasyid dalam Syamsuddin Haris, Kemajuan Budaya Dalam Globalisasi. Insani Press, Jakarta, 2002, hal. 2
} 
Sarbaini, Penyelenggaraan Pemilihan Kepala Daerah Secara Langsung dan Demokratis Sebagai Bentuk Perwujudan Hak Asasi Politik Masyarakat di Indonesia

didasarkan pada ketentuan UU No. 32 Tahun 2004 tentang Pemerintahan Daerah dengan berlandaskan pada ketentuan Pasal 18 ayat (4) UUD 1945 yang menentukan bahwa Gubernur, Bupati, dan Walikota masing-masing sebagai kepala pemerintahan daerah provinsi, kabupaten, dan kota dipilih secara demokratis. Apabila dicermati secara seksama, sesunggunnya ketentuan Pasal 18 ayat (4) UUD 1945 tersebut tidak menegaskan keharusan bahwa Gubernur, Bupati dan Walikota harus dipilih melalui suatu pemilihan yang dilaksanakan secara langsung. Akan tetapi, menurut Rozali Abdullah, oleh karena Daerah merupakan bagian yang tidak terpisahkan dari Negara Republik Indonesia, maka dalam melakukan pemilihan kepala daerah dan wakil kepala daerah seharusnya sinkron dengan pemilihan presiden dan wakil presiden, yaitu melalui pemilihan langsung. ${ }^{21}$

Setelah proses percepatan demokrasi secara beruntun tersebut berjalan kurang lebih lima tahun terhitung dari 1 Juni 2005, ternyata masih juga menyisakan banyak persoalan, bahkan agenda pemilihan kepala daerah secara langsung pun juga berkontribusi menambah beban politik, sosial bahkan beban finansial republik ini. Pemilihan kepala daerah secara langsung terlalu boros, dan tidak seimbang dengan cost politik yang telah dikorbankannya. Kenyataan yang tak terhindarkan dalam pemilihan kepala daerah secara langsung adalah muncul kapitalisasi dalam tahapan pemilihan kepala daerah. ${ }^{22}$ Dengan munculnya kapitalisasi ini maka pemilihan kepala daerah secara langsung jauh lebih mahal dibandingkan dengan model pemilihan kepala daerah lewat perwakilan DPRD. ${ }^{23}$

Dalam pelaksanaan pemilihan kepala daerah secara langsung selama ini, nuansa yang paling menonjol adalah maraknya sengketa pemilihan kepala daerah yang diajukan ke Mahkamah Konstitusi. Selain itu juga maraknya kepala daerah yang terpilih dalam pemilihan kepala daerah secara langsung yang terjerat kasus korupsi. Kabar tentang kepala daerah yang tersandung kasus korupsi tak pernah berhenti mengalir. Ironisnya, setiap minggu selalu ada kepala daerah yang ditetapkan sebagai tersangka dalam kasus korupsi. Umumnya, terjeratnya para kepala daerah itu terkait erat dengan proses pemilihan kepala daerah yang sudah menelan biaya cukup banyak. ${ }^{24}$ Pemilihan kepala daerah ini menjadi menarik untuk diteliti

\footnotetext{
${ }^{21}$ Rozali Abdullah, Pelaksanaan Otonomi Luas dengan Pemilihan Kepala Daerah Secara Langsung, Rajawali Pers, Jakarta, 2005, hal. 53.

${ }^{22}$ Amirudin dan A. Zaini Bisri, Pilkada Langsung: Problem dan Prospek,Pustaka Pelajar, Yogyakarta, 2006, hal.59

${ }^{23}$ Ibid

${ }^{24}$ Pernyataan ini disampaikan Menteri Dalam Negeri Gamawan Fauzi di hadapanpara peserta Rapat Kerja dengan Komite I DPD di Gedung DPD RI, Senayan,pertengahan Januari 2011 dan secara secara lugas Gamawan Fauzi menudingpelaksanaan Pilkada sebagai akar permasalahannya. Di mana seseorang yang berminatuntuk maju sebagai calon bupati, calon walikota ataupun calon gubernur harus siapmenanggung
} 
Sarbaini, Penyelenggaraan Pemilihan Kepala Daerah Secara Langsung dan Demokratis Sebagai Bentuk Perwujudan Hak Asasi Politik Masyarakat di Indonesia

terkait Rancangan Undang-Undang Pemilihan Kepala Daerah yang saat ini sedang disiapkan kementerian Dalam Negeri.

Dalam Rancangan Undang-undang Pemilihan Kepala Daerah tersebut diatur bahwa Pemilihan Gubernur dan Wakil Gubernur oleh DPRD. ${ }^{25}$ Ulasan mengenai pemilihan kepala daerah, baik secara langsung atau secara perwakilan melalui DPRD sebagaimana diuraikan di atas sesungguhnya menunjukkan bahwa pilihan akan bentuk pemilihan kepala daerah belumlah tuntas. Pasal 18 ayat (4) UUD 1945 yang merupakan landasan konstitusional pemilihan kepala daerah hanya menggariskan bahwa kepala daerah dipilih secara demokratis, namun Undang-Undang Nomor 32 Tahun 2004, menterjemahkan kalimat "dipilih secara demokratis" sebagaimana dinyatakan Pasal 18 ayat (4) sebagai pemilihan langsung.

Pemilihan kepala daerah secara langsung memiliki korelasi yang sangat erat dengan pelaksanaan kedaulatan rakyat. Dengan pemilihan kepala daerah secara langsung, rakyat dapat menentukan sendiri pemimpin di daerahnya, sehingga terjalin hubungan yang erat antara kepala daerah dengan rakyat yang dapat mendorong terwujudnya penyelenggaraan pemerintahan daerah yang demokratis dan partisipatif. Sistem pemilihan kepala daerah secara langsung memberikan beberapa kelebihan, yaitu: pertama, Kepala Daerah terpilih akan memiliki mandat dan legitimasi yang kuat karena didukung oleh rakyat yang memberikan suara secara langsung. Legitimasi merupakan hal yang sangat diperlukan oleh suatu pemerintahan yang sedang mengalami krisis politik dan ekonomi. Krisis legitimasi yang menggerogoti kepemimpinan kepala daerah akan mengakibatkan ketidakstabilan politik dan ekonomi di daerah. Kedua, Kepala Daerah terpilih tidak perlu terikat pada konsesi partai atau fraksi-fraksi politik yang telah mencalonkannya. Artinya, Kepala Daerah terpilih berada di atas segala kepentingan dan dapat menjembatani berbagai kepentingan tersebut. Apabila kepala daerah terpilih tidak dapat mengatasi kepentingan-kepentingan partai politik, maka kebijakan yang diambil cenderung merupakan kompromi kepentingan partai-partai dan seringkali berseberangan dengan kepentingan rakyat. Ketiga, Sistem pemilihan kepala daerah secara langsung lebih akuntabel dibandingkan sistem lain yang selama ini digunakan karena rakyat tidak harus menitipkan suaranya kepada anggota legislatif secara sebagian atau penuh.

pendanaan (materi) selama proses pemilihan kepala daerah berlangsung.Dalam sekali proses pemilihan mulai dari kampanye, kunjungan ke daerah-daerah hinggapembuatan atribut kampanye diperkirakan menghabiskan dana Rp 60 sampai 100 miliar.Lantas dari mana dana itu berasal, bisa dari hasil menjual barang-barang pribadinya ataumeminjam dari kanan-kiri. http://hminews.com/news/korupsi-kepala-daerahyang-terpilih-yangjadi-terdakwa/, diunduh tanggal 22 Mei 2011

${ }^{25}$ Pemilihan Oleh DPRD Untungkan Parpol Besar, KOMPAS, edisi 11 Februari 2015 
Rakyat dapat menentukan pilihannya berdasarkan kepentingan dan penilaian atas calon. Apabila Kepala Daerah terpilih tidak memenuhi harapan rakyat, maka dalam pemilihan berikutnya, calon yang bersangkutan tidak akan dipilih kembali. Prinsip ini merupakan prinsip pengawasan serta akuntabilitas yang paling sederhana dan dapat dimengerti oleh rakyat maupun politisi. Keempat, Check and balances antara lembaga legislatif dan eksekutif dapat lebih seimbang. Dengan sistem pemilihan kepala daerah secara langsung, kedudukan dan posisi kepala daerah sangat kuat sehingga DPRD sebagai lembaga legislatif daerah tidak dapat menekan kepala daerah atas suatu kebijakan yang dilakukan atau menekan kepala daerah untuk memenuhi kehendak dan tuntutan DPRD. Dengan demikian, kepala daerah dapat bekerja dengan tenang untuk mengimplementasikan program kerjanya tanpa harus terusik oleh tuntutan DPRD. Meskipun demikian, kepala daerah tetap harus memperhatikan pendapat DPRD terkait pelaksanaan fungsi DPRD sebagaimana diatur dalam peraturan perundang-undangan. Kelima, kriteria calon Kepala Daerah dapat dinilai secara langsung oleh rakyat yang akan memberikan suaranya. Oleh karena rakyat yang akan menentukan sendiri kepala daerahnya, maka rakyat dapat menentukan kriteria-kriteria ideal seorang calon kepala daerah. Dengan criteria yang ditentukan sendiri oleh rakyat, maka rakyat akan memilih salah satu pasangan calon kepala daerah. Dengan demikian pilihan rakyat ditentukan oleh rakyat itu sendiri. Namun yang juga harus diperhatikan bahwa sistem pemilihan kepala daerah secara langsung juga memiliki kelemahan-kelemahan, yaitu: Pertama, dana yang dibutuhkan sangat besar.

Pemilihan kepala daerah secara langsung membutuhkan dana atau anggaran yang sangat besar untuk kebutuhan operasional, logistik, dan keamanan. Besarnya biaya yang harus disiapkan dalam penyelenggaraan pemilihan kepala daerah secara langsung ini tidak hanya merupakan beban yang harus dipikul calon kepala daerah saja tetapi juga harus ditanggung pemerintahan daerah. Besarnya biaya dalam pemilihan kepala daerah secara langsung ini akan lebih berat lagi manakala penyelenggaraan pemilihan kepala daerah harus dilakukan dalam dua putaran (two round). Pemilihan kepala daerah secara langsung dalam era liberalisasi politik dengan kekuatan partai politik yang dominan, memungkinkan sekali yang bias bertempur di sana adalah mereka yang memiliki capital ekonomi dan politik yang kuat. ${ }^{26}$ Para pengusaha yang dekat dengan partai politik atau para incumbent yang kaya, adalah yang paling besar mendapatkan peluang masuk dalam bursa pencalonan dalam

${ }^{26}$ Amirudin dan A. Zaini Bisri, Pilkada Langsung: Problem dan Prospek, PustakaPelajar, Yogyakarta, 2006, hal.29 
Sarbaini, Penyelenggaraan Pemilihan Kepala Daerah Secara Langsung dan Demokratis Sebagai Bentuk Perwujudan Hak Asasi Politik Masyarakat di Indonesia

pemilihan kepala daerah. Atas dasar kemampuan financial dan kekuatan kapital ekonomi ini, maka yang dapat masuk dalam bursa kepemimpinan daerah bukanlah figur-figur yang berkompeten yang memiliki kapabilitas yang baik, akan tetapi hanya mereka yang termasuk dalam kelompok orang kaya atau memiliki kemampuan financial yang kuat. ${ }^{27}$

Kedua, membuka kemungkinan konflik antara elite dan massa. Pemilihan kepala daerah secara langsung membuka potensi terjadinya konflik, baik konflik yang bersifat elite maupun konflik massa secara horizontal. Konflik ini semakin besar kemungkinan akan terjadi pada masyarakat paternalistic dan primordial, dimana pemimpin dapat memobilisasi pendukungnya. Ketiga, aktivitas rakyat terganggu. Pemilihan kepala daerah secara langsung akan disibukkan aktivitas para calon dan partai politik pendukungnya untuk mengadakan kampanye dan menyebarkan isu-isu politik serta melakukan manuver-manuver langsung ke tengan masyarakat dengan maksud mempengaruhi pilihan rakyat. Oleh karena itu, dalam kesemarakan pelaksanaan pemilihan kepala daerah secara langsung, telah menimbulkan adanya gangguan terhadap aktivitas rutin masyarakat, dimana masyarakat akan turut disibukkan dengan kegiatan-kegiatan yang terkait pelaksanaan pemilihan kepala daerah tersebut.

Pelaksanaan pemilihan kepala daerah secara langsung merupakan koreksi atas pelaksanaan pemilihan kepala daerah melalui perwakilan rakyat di DPRD berdasarkan Undang-undang Nomor 22 Tahun 1999 tentang Pemerintahan Daerah. Koreksi atas sistem pemilihan kepala daerah ini dilakukan dengan diimplementasikannya payung hukum pelaksanaan pemilihan kepala daerah secara langsung, yakni Undangundang Nomor 32 Tahun 2004. Dalam perkembangan selanjutnya, Undang-undang Nomor 32 Tahun 2004 kemudian diubah dengan Undang-undang Nomor 12 Tahun 2008. Lahirnya Undang-undang Nomor 12 Tahun 2008 ini sesungguhnya tidak terlepas dari perdebatan yang berkembang di masyarakat menyangkut eksistensi pemilihan kepala daerah, yaitu apakah pemilihan kepala daerah itu masuk dalam rezim pemerintahan daerah atau rezim pemilihan umum.

Ketentuan Pasal 18 ayat (4) UUD 1945 sebagai dasar konstitusional pelaksanaan pemilihan kepala daerah, sesungguhnya lahir bersamaan dengan Pasal 18A dan Pasal 18B, yaitu pada perubahan kedua UUD 1945 dan dimasukkan dalam Bab tentang Pemerintahan Daerah. Selanjutnya Pasal 22E lahir melalui perubahan ketiga UUD 1945 tetapi tidak memasukkan Pasal 18 ayat (4) melainkan hanya ketentuan Pasal 18 ayat (3) yang mengatur mengenai DPRD. Hal ini, menurut Leo Agustina, setidaknya dapat diartikan bahwa

\footnotetext{
${ }^{27}$ Ibid
} 
Sarbaini, Penyelenggaraan Pemilihan Kepala Daerah Secara Langsung dan Demokratis Sebagai Bentuk Perwujudan Hak Asasi Politik Masyarakat di Indonesia

Konstitusi tidak hendak memasukkan pemilihan kepala daerah dalam pengertian pemilihan umum sebagaimana dimaksud dalam Pasal 22E ayat (1) yang menyebutkan "pemilihan umum dilaksanakan secara langsung, umum, bebas, rahasia, jujur, dan adil setiap lima tahun sekali”. ${ }^{28}$ Dalam Undang-undang Nomor 32 Tahun 2004, pemilihan kepala daerah tidak lagi dipilih melalui sistem perwakilan oleh DPRD, akan tetapi dipilih secara langsung oleh rakyat. Ini berarti pemilihan kepala daerah secara langsung memberi peluang bagi rakyat untuk ikut terlibat secara aktif dalam proses pengambilan keputusan yang sangat strategis dalam penyelenggaraan pemerintahan daerah melalui pemilihan kepala daerah secara langsung.

Undang-undang Nomor 32 Tahun 2004 yang mengatur tentang pemilihan kepala daerah secara langsung itu menggunakan rujukan atau konsideran Pasal 1, Pasal 18, Pasal 18A, dan Pasal 18B UUD 1945. Frase " kedaulatan di tangan rakyat" dan dipilih secara demokratis" agaknya menjadi sandaran pembuat Undang-undang Nomor 32 Tahun 2004 merumuskan diterapkannya pemilihan kepala daerah secara langsung untuk menggantikan pemilihan kepala daerah melalui sistem perwakilan melalui DPRD sebagaimana diatur dalam Undang-undang Nomor 22 Tahun 1999. Akan tetapi, kata "dipilih secara demokratis" ini menurut Susilo dapat ditafsirkan pemilihan langsung oleh rakyat atau pemilihan melalui perwakilan oleh DPRD. ${ }^{29}$ Untuk mewujudkan pemilihan Gubernur, Bupati, dan Walikota secara demokratis diperlukan media untuk membentuk dan menciptakan konsep yang tepat, yang kemudian dikenal dengan istilah pemilihan kepala daerah. Pemilihan kepala daerah merupakan media untuk melaksanakan pemilihan kepala daerah secara demokratis sesuai dengan amanat UUD 1945.

Persoalan mendasar mengenai pemilihan kepala daerah pada umumnya tersangkut pada pemahaman dan pemaknaan atas kata "demokratis" yang kemudian diperdebatkan menjadi pemilihan langsunglah yang disebut demokratis dan pendapat lain yang menyatakan pemilihan tak langsung pun sesungguhnya juga dapat demokratis. Mekanisme pemilihan kepala daerah disebut demokratis apabila memenuhi beberapa parameter. Robert Dahl, Samuel Huntington (1993) dan Bingham Powel (1978) sebagaimana dikutip Saukani, HR dan kawan-kawan mengatakan bahwa parameter untuk mengamati terwujudnya demokrasi antara lain: pemilihan umum, rotasi kekuasaan, rekrutmen secara terbuka, serta akuntabilitas

\footnotetext{
${ }^{28}$ Leo Agustina, Op.Cit. hal. 79

${ }^{29}$ Susilo, "Menyongsong Pilkada yang Demokratis", Artikel, Jurnal Legislasi Indonesia, Vol.2 No. 2 Juni 2005
} 
Sarbaini, Penyelenggaraan Pemilihan Kepala Daerah Secara Langsung dan Demokratis Sebagai Bentuk Perwujudan Hak Asasi Politik Masyarakat di Indonesia

publik. $^{30}$ Terkait kebijakan memilih sistem pemilihan secara langsung dalam pemilihan kepala daerah, tidak terlepas dari disahkannya Undang-undang Nomor 22 Tahun 2003 tentang Susunan dan Kedudukan Majelis Permusyawaratan Rakyat, Dewan Perwakilan Rakyat, Dewan Perwakilan Daerah, dan Dewan Perwakilan Rakyat Daerah.

Dalam Undang-undang Nomor 22 Tahun 2003, antara lain direposisi kewenangan dan fungsi DPRD, yakni fungsi meminta pertanggungjawaban kepala daerah dan memilih kepala daerah. Dengan hilangnya fungsi memilih kepala daerah oleh DPRD, berarti istilah pemilihan kepala daerah secara demokratis dalam Pasal 18 ayat UUD 1945 adalah pemilihan langsung oleh rakyat. Meskipun pemilihan secara langsung dipandang memiliki makna positif dari aspek legitimasi dan kompetensi, prase "dipilih secara demokratis" sebagaimana dimaksud Pasal 18 ayat (4) UUD 1945 tidak dapat diterjemahkan secara tunggal sebagai pemilihan secara langsung. Pemilihan secara tidak langsung atau perwakilan pun dapat diartikan sebagai pemilihan yang demokratis, sepanjang proses pemilihan yang dilakukan demokratis. ${ }^{31}$ Pemahaman ini didasarkan bahwa Negara Republik Indonesia berdasarkan UUD 1945 mengakui dan menghormati satuan-satuan pemerintahan daerah yang bersifat khusus atau bersifat istimewa sebagaimana diatur dalam Pasal 18B UUD 1945. Dengan demikian, pemahaman mendasar terhadap ketentuan pemilihan kepala daerah sebagaimana dimaksud Pasal 18 ayat (4) UUD 1945 terutama terkait prase “...dipilih secara demokratis” dapat dimaknai bahwa pemilihan kepala daerah dapat dilakukan dalam 2 (dua) cara, yaitu pemilihan secara langsung oleh rakyat atau pemilihan melalui perwakilan yang dilaksanakan oleh DPRD.

\section{Partisipasi Masyarakat Dalam Pemilihan Kepala Daerah Secara Langsung dan Demokratis di Indonesia}

Pembangunan yang berkesinambungan senantiasa menjadi perhatian utama masyarakat terhadap kinerja lembaga-lembaga pemerintahan, upaya pelaksanaan Demokratisasi sampai saat ini masi menjadi pertanyaan oleh semua pihak. Prinsip demokrasi yang mengisyaratkan pengakuan akan keberagaman juga belum sepenuhnya terwujud. Praktik demokrasi saat ini justru masih diwarnai bangkitnya politik identitas, bahkan seiring dengan menguatnya otonomi daerah, etnosentrisme juga mewarnai relasi kekuasaan di daerah. Disisi lain, globalisasi yang berkembang dewasa ini juga berdampak pada masuknya

\footnotetext{
${ }^{30}$ Saukani HR, Affan Gaffar, dan Ryass Rasyid, Otonomi Daerah dalam Negara Kesatuan, Pustaka Pelajar, Yogyakarta, 2002, hal. 12-13

${ }^{31}$ Ibid, hal. 72
} 
berbagai kepentingan global ke daerah. Oleh karena itu wacana praktik demokrasi saat ini, harus diakui bahwa penyelenggaran pemilu Kepala Daerah secara langsung merupakan awal upaya penyelenggaraan pemerintahan yang demokratis dalam sistem pemerintahan daerah yang semula sentralistis menjadi desentralistis. Implikasinya, terjadi pergeseran lokus kekuasan, dari pusat ke daerah. Pemilihan secara langsung kepala daerah dalam hal ini bupati dan walikota, melahirkan penafsiran-penafsiran negatip, terutama sikap partai politik yang berkuasa selalu melakukan penekanan terhadap birokrasi/pegawai Negeri Sipil (PNS). Birokrasi selalu diserahkan kerana politik praktis dalam pelaksanaan pemilukada.

Sejalan dengan itu Miftah Thoha mengemukakan bahwa; "Bagi partai politik yang memenangkan suara dalam pemilihan umum, maka partai politik dalam suatu sistem negara demokrasi bisa memimpin dan mengendalikan pemerintahan. Kehadiran partai politik dalam pemerintahan akan menjadi master dari birokrasi pemerintah. ${ }^{32}$ Dalam perkembangannya pengorganisasian birokrasi sangat diwarnai dengan ketidakpastian akibat peran Kepala daerah sebagai pembina kepegawaian di daerah dan peran partai politik yang saling bersaing dengan sangat dominan, Bupati/wali Kota dan partai-partai politik yang berkuasa seenaknya melakukan building block kekuasaan melalui dinas-dinas birokrasi yang strategis di jajaran pemerintahan sebagai sumber daya kelangsungan partai politik yang bersangkutan, program rekrutmen birokrasi ikut mengalami spoil system yang merajalela mulai dari pengangkatan, penempatan, promosi dan instrumen kepegawaian lainnya tidak didasarkan kriteria penilaian melainkan berdasarkan pertimbangan politik, golongan serta unsur-unsur lainnya di luar tugas birokrasi. Dengan demikian pemilihan umum kepala daerah secara langsung sejatinya ditujukan untuk memperdalam demokrasi di Indonesia. Namun selama ini pengalaman pemilukada langsung justru menimbulkan dampak negatif dalam kehidupan birokrasi khususnya di daearah. Semestinya harus bersikap netral dan tidak memihak kesalah satu partai atau calon kepala daerah. Selanjutnya Miftah Thoha mengungkapkan bahwa; "Birokrasi itu bekerja sesuai dengan profesionalisme yang dituntut kepadanya sepanjang massa, dan tidak boleh terkontaminasi oleh warna politik yang datang silih beganti memimpinnya. ${ }^{33}$ Untuk menjamin adanya kepastian hukum, atas sikap netralitas birokrasi/Pegawai Negeri Sipil telah ditegaskan dalam Undang-undang Nomor 43 Tahun 1999 tentang pokok-pokok kepegawaian.

\footnotetext{
${ }^{32}$ Parhandinata, Pertahungan Partai Politik Dalam Pemilukada, Jurnal Ilmu Pemerintahan, edisi 3 Nomor 1 Oktober 2015, Jatinagor, 2015, hal. 391

${ }^{33}$ Ibid
} 
Mencermati sejarah aturan hukum kepegawaian diera orde baru yaitu, Ketika Presiden Suharto pertama kali membentuk Kabinet Pembangunan I dengan Keputusan Presiden Nomor 19 Tahun 1968, dibentuk kementerian nomenklatur baru yaitu Kementerian Negara Penyempurnaan dan Pembersihan Aparatur Negara bertugas antara lain melanjutkan pembersihan birokrasi dari unsur-unsur apa yang disebut dengan berpolitik kepartaian lalu berdasarkan Keputusan Presiden Nomor 82 Tahun 1971 pada tanggal 29 Nopember 1971 didirikan Korps Pegawai Republik Indonesia sebagai organisasi wadah tunggal bagi seluruh pegawai Negeri Sipil. Dan dengan Keppres Nomor 45/M Tahun 1983 Kementerian Negara Penyempurnaan dan Pembersihan Aparatur Negara diubah kembali menjadi Kementerian Pendayagunaan Aparatur Negara yang secara langsung menteri pada kementerian tersebut merangkap pula sebagai wakil Ketua Bappenas.

Pada saat dimulainya reformasi maka melalui Peraturan Pemerintah Nomor 5 Tahun 1999 mengenai keberadaan pegawai negeri sipil (PNS) sebagai anggota partai politik lalu diubah melalui Peraturan Pemerintah Nomor 12 Tahun 1999 yang membuat pegawai negeri sipil (PNS) kembali tertutup dari kemungkinan untuk ikut berkiprah sebagai keanggotaan dalam partai politik apapun. Selanjutnya Deden Mariana Carolina Paskarina mengemukakan bahwa "pada prakteknya, sistem pemilihan kepala daerah langsung ini memang tidak secara otomatis membawa perubahan yang lebih baik dalam tata kelola pemerintahan daerah. ${ }^{34}$ Peluang money politics, manipulasi, politisasi adat dan ikatan primordial, serta mobilisasi massa tetap berlangsung. Para elit politik tetap berperan dominan dalam pilkada, minimal dalam menentukan pasangan calon yang akan berlaga dalam pilkada. Masyarakat hanya berperan dalam memberikan suara bagi para calon yang telah ditentukan para elit. Meskipun demikian, perlawanan masyarakat terhadap dominasi elit tetap ada. Tingginya persentase golput disejumlah daerah mengindikasikan sikap apatisme masyarakat.

Pemilihan umum kepala daerah merupakan suatu pesta rakyat yang diselenggarakan untuk memilih calon pemimpin, baik dalam ranah kabupaten maupun kota. Sesuai dengan asas pemilu yang Jujur, adil, langsung, umum, bebas, dan rahasia, maka diharapkan pelaksanaan Pemilu itu sendiri dapat berjalan secara netral dan tidak bersifat diskriminatif. Dengan adanya Badan Pengawas Pemilu (Bawaslu) dari KPU yang mengawasi jalannya pelaksanaan pemilu dapat dikatakan pelaksanaan Pemilu sudah profesional dan netral.Tetapi, pada faktanya di lapangan, tidak semua pelaksanaan Pemilihan Umum calon pemimpin di

\footnotetext{
${ }^{34}$ Deden Mariana Carolina Paskarina, Pemilihan Kepala Daerah, Litera Antar Nusa, Jakarta, 2014, hal. 
Sarbaini, Penyelenggaraan Pemilihan Kepala Daerah Secara Langsung dan Demokratis Sebagai Bentuk Perwujudan Hak Asasi Politik Masyarakat di Indonesia

suatu daerah bebas dari praktek-praktek kotor. Pemilihan Umum yang berlangsung diharapkan oleh sebagian besar masyarakat justru dinodai dengan praktek-praktek kecurangan dari pihak tim sukses maupun kecurangan dalam penghitungan suara. Hal ini merupakan suatu gambaran yang pilu bagi Pemilihan Umum di Indonesia, karena Pemilihan Umum yang diusung dengan asas keadilan dan netralitas ternyata dalam menyukseskannya harus dibayar dengan kecurangan. Berbagai macam bentuk kecurangan yang terjadi dalam Pemilihan Umum di daerah. Salah satunya adanya keterlibatan oknum PNS dalam menyukseskan Pemilukada.

Mengacu pada UU RI No 43 tahun 1999 tentang perubahan atas UU RI No 8 tahun 1974 tentang Pokok-Pokok Kepegawaian Pasal 3 ayat (1) menjelaskan bahwa PNS berkedudukan sebagai unsur aparatur negara yang bertugas untuk memberikan pelayanan kepada masyarakat secara profesional, jujur, adil, dan merata dalam penyelenggaraan tugas negara, pemerintahan, dan pembangunan. Pasal 3 ayat (2) dalam kedudukan dan tugas sebagaimana dimaksud dengan ayat (1), PNS harus netral dari pengaruh semua golongan dan parpol, serta tindak diskriminatif dalam memberikan pelayanan kepada masyarakat. Sedangkan pada Pasal 3 ayat (3) untuk menjamin netralitas PNS sebagaimana dimaksud dalam ayat (2), PNS dilarang menjadi anggota dan/atau pengurus parpol. ${ }^{35}$

Semasa berlakunya UU No. 32 Tahun 2004 tentang Pemerintahan Daerah, bahwa birokrasi atau PNS dibolehkan mencalonkan pilkada, hal ini didukung oleh peraturan tersebut di atas yang diberikan kesempatan oleh parpol atau gabungan parpol, jika dikaitkan dengan netralitas birokrasi dalam pilkada, terbukti birokrasi yang mencalonkan diri sebagai calon kepala daerah atau wakil kepala daerah berarti tidak netral, karena harus melalui parpol dan gabungan parpol (Pasal 59 ayat 1), dan juga diberikan kesempatan tetap berstatus sebagai PNS, karena hanya mengundurkan diri dari jabatan negeri yakni jabatan struktural dan jabatan fungsional (Pasal 59 ayat 5 (g), oleh karena itu, secara individu dijamin hak asasi manusianya. PNS atau birokrasi yang mencalonkan diri dalam pilkada, terbukti melanggar UU RI No 43 Tahun 1999 Pasal 3 ayat 1, 2, dan 3 karena tidak profesional mengingat jabatan pilkada adalah jabatan politik, sedangkan jabatan PNS adalah jabatan karir administratif sebagai pelayan masyarakat yang harus netral, sedangkan jabatan pilkada terkait dengan parpol atau gabungan parpol, dengan demikian melanggar pasal 3 ayat 2 dan ayat 3, sehingga secara institusional birokrasi atau PNS dibatasi hak politiknya. Hal ini dapat dilihat dari penjelasan mengenai keterlibatan birokrasi/PNS dalam keikutsertaan dalam Pemilihan

\footnotetext{
${ }^{35}$ Ibid, hal. 193
} 
Sarbaini, Penyelenggaraan Pemilihan Kepala Daerah Secara Langsung dan Demokratis Sebagai Bentuk Perwujudan Hak Asasi Politik Masyarakat di Indonesia

Umum. Dengan adanya keberpihakan suatu oknum pemerintahan dalam penyelenggaraan pemilihan kepala daerah merupakan suatu bentuk dari ketidakadilan dalam Pemilu, di mana masih adanya para oknum pemerintahan yang menggunakan kekuasaannya sebagai "roda penggerak" dalam menyukseskan suatu kelompok dalam kancah perpolitikan. Dijelaskan dalam Undang-Undang Kepegawaian bahwa Pegawai Negeri Sipil (PNS) tidak boleh berpihak kepada satu pihak dan harus bersikap netral dalam menjalankan tugas dan juga dilarang menjadi anggota dan / atau pengurus parpol.

Di samping permasalahan di atas, adanya suatu pelanggaran lainnya yang melibatkan oknum pemerintahan, seperti adanya petugas penyelenggara tingkat desa, kecamatan, kabupaten tidak bertindak netral dalam menjalankan tugas penyelenggaraan pemilukada dan adanya penggunaan dana APBD untuk menjalankan kampanye. Pada permasalahan di atas, dapat dijelaskan bahwa masih tidak berlakunya asas keadilan dalam pemilihan umum yang diselenggarakan, dengan adanya keikutsertaan dari oknum-oknum pemerintahan, maka pelaksanaan dari pemilihan umum bersifat lebih mengedepankan kepentingan kelompok dibandingkan kepentingan umum, karena banyak dari oknum pemerintahan yang menyalahgunakan wewenang dalam menjalankan tugasnya untuk mendukung salah satu calon kandidat dalam Pemilukada. ${ }^{36}$ Kalau dilihat dari berbagai sisi bahwa semua stakeholder ingin mengupayakan pentingnya untuk melihat proses Pilkada sebagai bagian integral dari proses demokratisasi di Indonesia, dengan mengupayakan semua penyelenggaraan pemilu yang berdasarkan asas-asas pemilu yang berdasarkan UU No. 15 Tahun 2011 yang terdiri dari mandiri, jujur, adil, kepastian hukum, tertib, kepentingan umum, keterbukaan, proporsionalitas, profesuionalitas, akuntabilitas, efisiensi dan efektifitas, namun ketika melihat berbagai permasalahan di daerah tentang netralitas birokrasi PNS yang cenderung menjadi" roda politik".

Bagaimana birokrasi yang seharusnya melayani masyarakat malah terjun dalam ranah politik yang cenderung tidak netral, sehingga dirasa perlu untuk mengembalikan citra birokrasi yang harus netral secara politik, namun upaya tersebut dirasakan sangat tidak mudah karena banyak berbagai faktor yang menjadi kendala didalam mengupayakan birokrasi yang netral secara politik dan melayani masyarakat secara lebih adil dan berasaskan kepentingan umum. Kondisi politik di Indonesia pada saat ini, baik di infrastruktur maupun suprastruktur masih belum stabil, kompetisi antar partai politik tidak dilakukan dengan sehat tetapi dengan menggunakan cara dan strategi yang dapat menimbulkan konflik baru.

\footnotetext{
${ }^{36}$ Ibid, hal 196
} 
Kedewasaan para elite politik yang masih sangat memprihatinkan dan memberikan contoh yang kurang baik bagi masyarakat menjadi salah satu hal yang menciptakan kondisi politik seperti itu di Indonesia. Dengan kondisi seperti itu Politik yang biasanya sebagai pengendali birokrasi tidak bisa menjalankan perannya secara optimal. Bahkan para elite politik yang berkuasa menghendaki birokrasi menjadi miliknya yang akan dijadikan alat untuk melanggengkan kekuasaan. Politik terhadap Birokrasi yang begitu kuat baik dari legislatif terlebih dari pimpinan eksekutif menimbulkan netralitas birokrasi hanya dalam tatanan konsep. Namun demikian birokrasi tidak bisa dikuasai dengan mudah, birokrasi yang telah dibentuk sejak sebelum kemerdekaan dan telah memiliki pola pikir tersendiri. Sehingga pergantian elite politik atau rezim yang berkuasa tidak serta merta akan merubah pola pikir dan kebiasaan yang ada pada birokrasi. Bahkan tidak tertutup kemungkinan para elite politik akan tergiring atau terbawa arus pada pola pikir dan kebiasaan birokrasi. Kebijakan-kebijakan yang reformis di tingkat elite politik tidak bisa diturunkan atau dilaksanakan di lapangan karena Birokrasi memiliki kebijaksanaan dan kepentingan tersendiri. Akhirnya kebijakankebijakan tersebut tidak pernah dapat direalisasikan.

Mengenai sistem, prosedur dan kebiasaan yang sekian lama tertanam dan terbentuk dalam Birokrasi tidak serta merta dapat dirubah, daya resistensi yang begitu tinggi terutama dari elite-elite birokrasi yang telah menikmati keuntungan-keuntungan dari sistem yang ada menjadikan ingin tetap mempertahankannya. Adanya resistensi tersebut diperkuat dengan suatu aturan yang menempatkan kekuasaan tersentralisir di tangan pimpinan tertinggi organisasi. Perubahan sulit dilakukan dari bawah karena akhirnya bermuara ke atas dan yang menentukan adalah dari atas/pimpinan. Ide dan gagasan yang konstruktif dan reformatif dari bawah akan menghasilkan kebijakan dan kebijaksanaan konservatif yang defensif dari atas. Aspek sosial budaya baik yang ada dalam birokrasi maupun yang melingkupi birokrasi turut serta berperan dalam mempengaruhi proses reformasi birokrasi, tanpa dukungan sosial budaya proses reformasi akan sulit dilakukan. Kegagalan penerapan sistem-sistem barat yang diadopsi negara berkembang disebabkan oleh tidak sinkron atau kurang memperhatikan aspek sosial budaya. Aspek sosial budaya yang ada akan membentuk perilaku dan pola pikir aparat birokrasi dan masyarakat. Perilaku dan pola pikir yang berkembang di masyarakat dan aparat birokrasi yang kurang mendukung antara lain:

(a) Budaya kita yang terlalu mengagung-agungkan simbol, mendorong birokrasi kita lebih menonjolkan aspek formalitas. Kegiatan-kegiatan yang dilakukan asal dapat terlaksana kualitas pekerjaan tidak menjadi perhatian. Begitu juga halnya orang 
melihat orang lain bukan didasarkan pada keahliannya tetapi kepada sertifikat/ijazah (simbol) yang dimilikinya.

(b) Kesuksesan seseorang hanya dilihat dari aspek materi, orang akan lebih menghormati orang yang memiliki kekayaan dari pada yang biasa-bisa sehingga pelayanan yang diberikan akan berbeda-beda.

(c) Budaya Paternalisme dan senioritas, pimpinan selalu dianggap yang serba tahu dan harus memberikan suri tauladan dan bawahan akan berpatokan pada contoh-contoh yang diberikan pimpinannya. Untuk menjadi pimpinan dilakukan dengan pendekatan senioritas dengan asumsi orang yang lebih tua telah memiliki asam garam yang lebih banyak dan tentu saja akan memiliki keahlian dan kemampuan yang lebih baik.

(d) Budaya kekerabatan (nepotisme) yang kental dalam masyarakat kita dan dalam birokrasi kita, penerapannya dilakukan secara buta tanpa memandang aspek atau faktor yang lain. Dalam prakteknya pengangkatan pejabat atau penerimaan pegawai tanpa memandang keahlian dan kemampuan tapi hanya melihat siapa dia apakah kerabat atau bukan kerabat.

(e) Budaya permisif, masyarakat terkadang terlalu mentolelir kelakuan-kelakuan yang menyimpang sehingga menjadi kebiasaan dan orang tidak takut melakukannya bahkan karena dibiarkan menjadi dianggap benar dan orang lain ikut melakukannya. ${ }^{37}$

Dengan dipetakannya dan dipahaminya Kendala dan permasalahan yang dihadapi, kemudian dibandingkan dengan kondisi ideal yang ingin diwujudkan yakni netralitas birokrasi (PNS) pada pilkada, maka akan diketahui positioning Birokrasi Indonesia. Didasarkan pada kenyataan tersebut maka langkah netralitas birokrasi (PNS) harus dilakukan secara terintegrasi dan terpadu serta dilakukan secara sistematis. Untuk itu langkah berikutnya adalah merumuskan dan menetapkan grand design (blue print) dalam pelaksaan pilkada sebagai rencana strategis dalam menata birokrasi.

Adanya Badan Pengawas Pemilu (Bawaslu) yang mengawasi jalannya pelaksanaan pemilu dapat dikatakan pelaksanaan Pemilu sudah profesional dan netral. Tetapi, pada faktanya di lapangan, tidak semua pelaksanaan Pemilihan Umum calon pemimpin di suatu daerah bebas dari praktek - praktek kotor. Pemilihan Umum yang diharapkan oleh sebagian

${ }^{37}$ Bondan Gunawan, Demokrasi, Kebebasan dan Hak Asasi Manusia, Rineka Cipta, Jakarta, 2014, hal, 
Sarbaini, Penyelenggaraan Pemilihan Kepala Daerah Secara Langsung dan Demokratis Sebagai Bentuk Perwujudan Hak Asasi Politik Masyarakat di Indonesia

besar masyarakat justru dinodai dengan praktek - praktek kecurangan dari pihak tim sukses maupun kecurangan dalam penghitungan suara. Hal ini merupakan suatu gambaran yang pilu bagi Pemilihan Umum di Indonesia, karena Pemilihan Umum yang diusung dengan asas keadilan dan netralitas ternyata dalam menyukseskannya harus dibayar dengan kecurangan. Menurut Yunafarhan bahwa peran Pegawai Negeri Sipil dari berbagai aspek yaitu:

1. Sebagai pelaksana peraturan dan perundangan yang telah ditetapkan pemerintah. Untuk mengemban tugas ini netralitas PNS sangat dibutuhkan.

2. Melakukan fungsi manajemen pelayanan pablik. Ukuran yang dipakai untuk mengepaluasi peran ini adalah seberapa jauh masyarakat puas atas pelayanan yang diberikan PNS. Apabila tujuan utama otonomi daerah adalah mendekatkan pelayanan kepada masyarakat, sehingga desentralisasi dan otonomi terpusat pada pamerintah kabupaten dan kota, maka PNS pada daerah-daerah tersebut mengerti benar keinginan dan harapan masyrakat setempat.

3. PNS harus mampu mengelola pemerintahan. Artinya pelayanan pada pemerintah merupakan fungsi utama PNS. Setiap kebijakan yang diambil pemerintah harus dapat dimengerti dan dipahami oleh setiap PNS. Sehingga dapat dilaksanakan dan disosialisasikan sesuai dengan tujuan kebijakan tersebut. Dalam hubungan ini maka manajemen dan administrasi PNS harus dilakukan secara terpusat, meskipun fungsifungsi pemerintahan lain telah diserahkan kepada pemerintah kota dan pemerintah kabupaten dalam rangka otonomi daerah yang diberikan saat ini. ${ }^{38}$

Mengacu pada hal tersebut maka dalam masa mendatang manajemen kepegawaian akan dihadapkan pada berbagai tantangan yang tidak ringan yaitu;

1. Sejauh mana sistem kepegawaian mampu bertahan dari tekanan politik. Dalam sistem multi partai yang menyebabkan pemimpin institusi pemerintah baik dipusat maupun didaerah, berasal dari partai-partai poltik, mampukah PNS bersikap netral? Artinya jenjang karir dari PNS telah tersusun rapi sehingga tidak ada jabatan karir yang akan diisi oleh personil dari suatu partai atau golongan tertentu saja.

2. Sejauh mana sistem kepegawaian mampu menerjemahkan setiap peraturan perundangan yang dikeluarkan pemerintah tanpa meninggalkan asas netralitas dan peran sebagai perekat kesatuan dan persatuan dalam hal ini profesionalitas dan Integritas dalam diri setiap PNS dipertaruhkan. Untuk itu perlu dijaga tingkat kesejahteraan dan stabilitas dari PNS beserta keluarganya.

\footnotetext{
${ }^{38}$ Ibid, hal. 89
} 
Sarbaini, Penyelenggaraan Pemilihan Kepala Daerah Secara Langsung dan Demokratis Sebagai Bentuk Perwujudan Hak Asasi Politik Masyarakat di Indonesia

3. Sejauh mana budaya kepegawaian dapat ditumbuhkan. Artinya ada rasa kebanggaan menjadi PNS. Ini sangat berhubungan dengan tantangan pertama dan kedua. Sampai dimana Netralitas dan profesionalisme PNS masih dapat diharapkan. Justru untuk mempertahankan kedua sifat tersebut pengaturan kepegawaian yang terpusat masih diperlukan.

4. Sejauh mana manajemen kepegawaian mampu mengikuti perkembangan teknologi informasi. $^{39}$

Melihat jalannya pemilukada langsung yang kian tidak karuan itu, agar akhlak masyarakat tidak makin rusak, sangatlah mendesak untuk segera membenahinya. Apabila kita terlambat, dikhawatirkan Indonesia akan meraih predikat sebagai negara dengan jumlah kepala daerah/wakil kepala daerah dan pejabat publik lokal paling banyak terjerat masalah hukum di dunia.

\section{Daftar Pustaka}

Dahlan Thaib, Teori dan Hukum Konstitusi, Liberty, Yogyakarta, 2006.

Majda El Muhtaj, Dimensi-Dimensi HAM Mengurai Hak Ekonomi, Sosial, dan Budaya, Jakarta, PT. Rajawali Pers, 2008.

A.Gunawan Setiardja, Hak-Hak Asasi Manusia Berdasarkan Ideologi Pancasila, Kanisius, Yogyakarta, 1993.

Ifdhal Kasim (Editor), Hak Sipil dan Politik Esai-Esai Pilihan. Cetakan Pertama. Jakarta. Lembaga Studi dan Advokasi Masyarakat (ELSAM), 2001.

H. Rosjidi Ranggawidjaja, Pembatasan Hak Asasi Manusia Menurut Hukum dan Konvensi Internasional, Djambatan, Jakarta, 2000.

Satya Arinanto, Politik Hukum 3, Program Pasca Sarjana Fakultas Hukum Universitas Indonesia,Jakarta, 2001.

Satjipto Rahardjo, Penegakan Hukum Sosiologis Suatu Tinjauan Sosiologis, Genta Publishing, Semarang, 2009.

Nick Hungtingtong, Paradoks Demokrasi, Yayasan Obor, Jakarta, 2005.

M.Rias Rasyid dalam Syamsuddin Haris, Kemajuan Budaya Dalam Globalisasi. Insani Press, Jakarta, 2002,

Rozali Abdullah, Pelaksanaan Otonomi Luas dengan Pemilihan Kepala Daerah Secara Langsung, Rajawali Pers, Jakarta, 2005.

Amirudin dan A. Zaini Bisri, Pilkada Langsung: Problem dan Prospek,Pustaka Pelajar, Yogyakarta, 2006.

Saukani HR, Affan Gaffar, dan Ryass Rasyid, Otonomi Daerah dalam Negara Kesatuan, Pustaka Pelajar, Yogyakarta, 2002.

Deden Mariana Carolina Paskarina, Pemilihan Kepala Daerah, Litera Antar Nusa, Jakarta, 2014.

Bondan Gunawan, Demokrasi, Kebebasan dan Hak Asasi Manusia, Rineka Cipta, Jakarta, 2014.

\footnotetext{
${ }^{39}$ Ibid, hal. 97
} 